\title{
Cefminox Sodium
}

National Cancer Institute

\section{Source}

National Cancer Institute. Cefminox Sodium. NCI Thesaurus. Code C98223.

The sodium salt form of cefminox, a semi-synthetic, second-generation, betalactamase-stable cephalosporin with antibacterial activity. 